\title{
Status, Scope and Constraints of Farm Mechanization in Jammu and Kashmir State of India
}

\author{
Sunny Raina*, Hemant Dadhich, Anil Kumar, Brinder Singh and Jai Kumar \\ Advanced Centre for Rainfed Agriculture, SKUAST-J, Jammu, India \\ *Corresponding author
}

\section{A B S T R A C T}

\begin{tabular}{|l|}
\hline Ke y w o r d s \\
$\begin{array}{l}\text { Mechanization status, } \\
\text { Mechanization potential } \\
\text { agricultural operations, } \\
\text { Farm power }\end{array}$ \\
\hline Article Info \\
\hline $\begin{array}{l}\text { Accepted: } \\
\text { 12 February } 2018 \\
\text { Available Online: } \\
\text { 10 March } 2018\end{array}$ \\
\hline
\end{tabular}

A study indicates that there is increase in area, production and productivity of major food crops in Jammu \& Kashmir State of India over the years but the rate of increase has been slow. Jammu region of the State has maximum cropping intensity (176.8\%) followed by Kashmir (123\%) and Ladakh (106\%). The average land holding in the State is very low (0.66 ha) in comparison to National Average (1.68 ha). The unit farm power availability on gross cropped area basis is $0.78 \mathrm{~kW}$ contributed $51.2 \%$ by animated (human and animal power) sources and $48.8 \%$ from rest of the sources. The present agricultural production is insufficient to mitigate the requirement of growing population due to the limited scope of increase in cultivable area and low level of mechanization. The bottleneck in mechanization are due to non-availability of improved equipment, small and scattered land holding, low investing capacity of the farmers and lack of awareness among farmers. Despite these, there is a great need and effort to increase the productivity and reduce the drudgery through mechanization inputs.

\section{Introduction}

Jammu \& Kashmir is India's northernmost state, lying between six mountain ranges and covering an area of 2,22,236 sq. $\mathrm{km}$. It is located between $32^{\circ} 17^{\prime}$ and $36^{\circ} 58^{\prime}$ North latitude, and between $37^{\circ} 26^{\prime}$ and $80^{\circ} 30^{\prime}$ East longitude. The state is commonly known as Kashmir, the territory is bounded on the north by Afghanistan and China, on the east by China, on the south by the state of Himachal Pradesh and the state of Punjab in India, and on the west by the North-West Frontier Province and the Punjab Province of Pakistan. Jammu \& Kashmir has three distinct regions viz. Ladakh, Jammu and Kashmir valley - The
Kashmir valley receives good rainfall and has rich soils though the temperate zones of Ladakh face climatic barriers against agricultural growth. High soil erosion also reduces fertility. The State has three sub zones. Agriculture is and would continue to be the major source of income and employment for the people of State, due to limited resource endowments in other sector. An area of 2,236 sq. $\mathrm{km}$ is covered by forests. The majority of the net geographical area of the State $(101,387$ $\mathrm{km}^{2}$ ), excluding the area under the occupation of Pakistan and China, is rural with 6652 villages (Anonymous 2006-2007). The agriculture and its allied sectors provide about $36 \%$ of the net domestic product and engage 
about $80 \%$ of the population. Draught animals are the main source of farm power. Animal drawn implements such as Indigenous, Tawi, Hill and Soil stirring plough are employed for land preparation activities. Small and marginal farmers still use the manual tillage tools such as spades, shovels, sickle, hand forks while farmers in plain topography use tractors and implements for tillage and transportation purpose (Dixit et. al., 2006; Sharma, 2010). Farm work is generally labour intensive and demands considerable amount of energy. In general level of mechanization in the State is low. Although there is abundance of water received through precipitation (snowfall and rainfall) in the State except in Ladakh region, the major portion is utilized in the lower part of the State and in Pakistan. Only $41.7 \%$ of the net sown area is irrigated by different sources and remaining area is rainfed. The major source of irrigation is through canals (93.0\%). Similarly, the natural energy sources like sunshine, wind, vegetation, water flow and other biological wastes which are abundantly available in the State are not being harnessed properly, resulting in very low per capita energy availability, deforestation and poor health. In 2016, net state domestic product for Jammu \& Kashmir was 100,341 Indian rupees. Net state domestic product of Jammu \& Kashmir increased from 7,851 Indian rupees in 1997 to 100,341 Indian rupees in 2016 growing at an average annual rate of $14.71 \%$., while per capita income increased from Rs. 21734 to Rs. 58593 during period from 2004-05 to 2013-14. There are 13.35 lakh land holdings in the State with a population of 101.44 lakh. Nearly $82 \%$ of the total geographical area is not available for cultivation whereas rest $18 \%$ area is being used for agriculture and other allied activities of which only $7.36 \%$ is the net sown area (Table 1). Agriculture sectors during the postindependence era have shown considerable transformation, whereas the net sown area has increased from 0.614 million ha to 0.736 million ha during the last more than 60 years. It is estimated that there is a net deficit of 0.35 million $t$ food grain to ensure food and nutritional security of State population. Keeping these in view, present study was taken up to analyse agricultural and allied scenario of the State with an emphasis on its mechanization aspects.

\section{Materials and Methods}

Information was collected from possible sources on the location, topography, soil type, climate, population, \%age of people engaged in agriculture, farming system adopted by farmers, principle crops cultivated in the region and other related activities. The data were used to draw some meaningful conclusions.

\section{Results and Discussion}

\section{General topography}

The State can be divided into four agroecological regions as shown in Table 2.

There are numerous micro-agro-climatic zones in the region which makes it feasible to cultivate almost all types of agricultural as well as horticultural crops. These crops include cereals, pulses, oilseed, vegetables, fruits, dry fruits, spices and ornamentals. Horticultural crops well adapted to the region includes fruits (apple, almond, walnut, plum, peach, cherry and apricots), vegetables (brinjal, chillies, potato, pea, cabbage, tomato, cauliflower, knoll khol, turnips, onion, garlic etc.), spices (kala zeera and saffron), and flowers (rose, tulip, gladiolus, marigold, carnation, nargis etc.). Forest occupies 6.5\% of the net geographical area of the State. The agrarian economy of the hills is heavily dependent on forest and pasture lands, for energy supply, fodder, non-timber products and livestock rearing. This vital sector of the 
State economy, however, due to high biotic pressure and abiotic factors is degrading. There has been a gradual decrease in the dense forest area.

Cultivable lands are limited; little scope of cultivating fodder as a result of livestock pressure is relatively higher in the region than in the plains. Cold-water aquaculture has a vast potential for horizontal and vertical expansion. The State has also vast potential of hydroelectric power, which has not been fully tapped. There is paucity of electrical power, which hampers agro-industrial and socioeconomic development.

\section{Climate and annual rainfall}

The climate of the state ranges from the scorching heat of the plains of (Jammu Division) to the snow-capped heights of Gulmarg (Kashmir) and the mud peak of Mount Godwin Austin (Ladakh) 21,265 feet above sea level. Broadly, the state of Jammu and Kashmir comprises of three distinct climatic regions: cold arid desert areas of Ladakh, temperate Kashmir Valley, and the humid sub-tropical region of Jammu. The mean annual rainfall in cold arid zone (Ladakh region) varies from $100 \mathrm{~mm}$ to $300 \mathrm{~mm}$ received by western disturbance. The annual rainfall in temperate region (Kashmir valley \& Pir Panjal) varies from $600-900 \mathrm{~mm}$ and added with snowfall. Leh is the coldest and Jammu is the hottest area. Mean monthly temperature is lowest in January and highest in July except in Jammu where highest temperature is experienced in June. Mean monthly temperature in January varies from $17^{\circ} \mathrm{C}$ at Drass to $14^{\circ} \mathrm{C}$ at Jammu. January 15 to March 15 is ice cold season when temperature in most of the areas in Kashmir is below $0^{\circ} \mathrm{C}$. It snows during winter.

The average annual rainfall also varies from region to region with $92.6 \mathrm{~mm}$ in Leh, 650.5 $\mathrm{mm}$ in Srinagar and $1115.9 \mathrm{~mm}$ in Jammu. A large part of the state forms part of the Himalayan Mountains. The state is geologically constituted of rocks varying from the oldest period of the earth's history to the youngest present day river and lake deposits.

\section{Type of soil}

The skeletal and calcareous soils with alkaline reaction and low to medium in organic matter content occur on gently sloping to Ladakh region. The rest of the region have soils which are shallow to deep loamy with little clay content, forest and podzolic brown with medium to high organic matter and acidic in reaction. Poor in lime but with a high content of magnesia, the soil is treated with chemical fertilisers and enriched with green manure and legume before cultivation. There is sufficient organic matter and nitrogen content in the alluvium of the Kashmir valley as a result of plant residue, crops stubble, natural vegetation and animal excretion.

\section{Operational land holding pattern}

The average size of operated land holding in $\mathrm{J} \& \mathrm{~K}$ is 0.6 ha, which is half than average operated holding size in India (Table 3). The fragmentation of land holding is expected to be greater, especially under small and marginal farmers' categories in the State. Majority of the farmers $(83.3 \%)$ in the State is marginal having less than 1 ha land holding.

\section{Brief scenario of agriculture}

Agriculture, the predominant sector of the economy of Jammu and Kashmir, supports about $80 \%$ of its population. Rice is the chief crop of Kashmir zone, followed by maize, barley and wheat. Jammu region dominates both in maize and wheat production. In the Ladakh region, barley is the major cereal crop followed by wheat. 
Table.1 Land resource utilization in Jammu \& Kashmir (2009-10)

\begin{tabular}{|l|}
\hline Land use \\
\hline Total geographical area \\
\hline Forests \\
\hline Land put to non-agriculture uses \\
\hline Barren and uncultivable land \\
\hline Pasture \\
\hline Land under Misc. tree crops \\
\hline Culturable waste land \\
\hline Fallow land other than current fallows \\
\hline Current fallows \\
\hline Net area sown \\
\hline Area sown more than once \\
\hline Total cropped area \\
\hline Net area under irrigation \\
\hline
\end{tabular}

\begin{tabular}{|l|l|}
\hline Area ('000 Ha) & $\begin{array}{l}\% \text { of geographical } \\
\text { area of State }\end{array}$ \\
\hline 22224 & - \\
\hline 658 & 2.96 \\
\hline 306 & 1.38 \\
\hline 274 & 1.23 \\
\hline 120 & 0.54 \\
\hline 63 & 0.28 \\
\hline 149 & 0.67 \\
\hline 26 & 0.12 \\
\hline 84 & 0.38 \\
\hline 735 & 3.31 \\
\hline 409 & 1.84 \\
\hline 1144 & 5.15 \\
\hline 317 & 1.43 \\
\hline
\end{tabular}

Table.2 Agro-ecological regions and livelihood production system in Jammu \& Kashmir State

\begin{tabular}{|l|}
\hline Region \\
\hline Region I Sulb-mountain and \\
\hline low Hills \\
\hline Region II \\
Mid Hills \\
\hline Region III \\
High Hills \\
\hline Region IV \\
Very High Hills \\
\hline
\end{tabular}

$\begin{aligned} & \text { Climate, Altitude (m, } \\ & \text { amsl) }\end{aligned}$
$\begin{aligned} & \text { Sub-tropical } \\ & 200-800\end{aligned}$
$\begin{aligned} & \text { Sub humid } \\ & 801-1,800\end{aligned}$
$\begin{aligned} & \text { Temperate } \\ & 1,801-2,200\end{aligned}$
Temperate dry
$>2,200$

\begin{tabular}{l|}
\hline $\begin{array}{l}\text { Livelihood production } \\
\text { system }\end{array}$ \\
\hline $\begin{array}{l}\text { Agril. Live stock } \\
\text { Fish, horticulture }\end{array}$ \\
\hline Agri-horti livestock, fish \\
\hline $\begin{array}{l}\text { Agri-horti livestock, pasture } \\
\text { fish }\end{array}$ \\
\hline $\begin{array}{l}\text { Livestock- silviculture- } \\
\text { agriculture }\end{array}$
\end{tabular}

Parts of State

Jammu and plains of Udhampur district

Hilly areas of Doda, Udhampur, Rajouri and Poonch districts

Srinagar, Budgam, Anantnag, Pulwama,baramulla and Kupwara districts agriculture

Table.3 Operational land holding pattern by major size groups in the region

\begin{tabular}{|c|c|c|c|c|c|c|c|}
\hline \multirow[t]{2}{*}{ Class } & \multirow{2}{*}{$\begin{array}{l}\text { Size of } \\
\text { holding, } \\
\text { ha }\end{array}$} & \multicolumn{2}{|c|}{$\begin{array}{l}\text { No. of operational } \\
\text { holding, }{ }^{6} 000\end{array}$} & \multicolumn{2}{|c|}{$\begin{array}{l}\% \text { distribution } \\
\text { operated }\end{array}$} & \multicolumn{2}{|c|}{$\begin{array}{l}\text { Av. Size of operational } \\
\text { holding, ha }\end{array}$} \\
\hline & & J\&K & India & J\&K & India & J\&K & India \\
\hline Medium & $>1$ & 1207 & 35410 & 83.3 & 67 & 0.3 & 0.4 \\
\hline Small & $1-2$ & 167 & 24705 & 11.5 & 17.9 & 1.4 & 1.4 \\
\hline Semi-medium & $2-4$ & 64 & 13840 & 4.4 & 10 & 1.7 & 2.7 \\
\hline Medium & $4-10$ & 11 & 5856 & 0.7 & 4.3 & 5.6 & 5.8 \\
\hline Large & $>10$ & 1 & 1000 & 0.1 & 0.8 & 12.0 & 17.4 \\
\hline Total & & 1449 & 137757 & 100 & 100 & 0.6 & 1.2 \\
\hline
\end{tabular}

Digest of statics of Jammu and Kashmir (2015-16) and Statistical Abstract India (2011). 
Table.4 Area, production and yield of important crops in Jammu and Kashmir

\begin{tabular}{|c|c|c|c|c|c|c|c|}
\hline \multirow[t]{2}{*}{ S. No } & \multirow[t]{2}{*}{ Crop } & \multicolumn{2}{|c|}{ Area ('000 Ha) } & \multicolumn{2}{|c|}{$\begin{array}{l}\text { Production } \\
\text { Qtls) }\end{array}$} & \multicolumn{2}{|c|}{ Yield (Qt/ha) } \\
\hline & & 2013-14 & 2014-15 & 2013-14 & 2014-15 & 2013-14 & 2014-15 \\
\hline 1 & Rice & 271.49 & 265.88 & 5567.38 & 4548 & 20.51 & 17.11 \\
\hline 2 & Maize & 298.68 & 308.82 & 5305.3 & 2735 & 17.76 & 8.86 \\
\hline 3 & Wheat & 292.07 & 290.99 & 6018.81 & 5819.5 & 20.61 & 20.0 \\
\hline 4 & Barley & 12.52 & 12.63 & 71.02 & 71.6 & 5.67 & 5.67 \\
\hline 5 & Pulses & 25.79 & 26.57 & 138.38 & 84.1 & 5.37 & 3.17 \\
\hline \multirow[t]{2}{*}{6} & Oilseeds & 65.73 & 65.95 & 588.36 & 583.8 & 8.95 & 8.85 \\
\hline & Total & 966.28 & 970.64 & 17689.25 & 13842 & 18.22 & 14.26 \\
\hline
\end{tabular}

Table.5 Indicators of agricultural mechanization in Jammu and Kashmir (2015-2016)

\begin{tabular}{|l|l|l|}
\hline S. No & Items & Value \\
\hline 1 & Gross Cropped Area (in '00' ha) & $\mathbf{1 1 5 8 9}$ \\
\hline 2 & Agricultural workers (no./ '00'ha) & \\
\hline 3 & Farm power availability (kW/ha) & $\mathbf{0 . 7 8}$ \\
\hline 4 & Draught animals (no./ '00' ha) & $\mathbf{1 3 2}$ \\
\hline 5 & Diesel / electric pump (no) & $\mathbf{1 . 8 4}$ \\
\hline 6 & Tractor (no./ '00' ha) & $\mathbf{1 . 1}$ \\
\hline 7 & Paddy thresher (no./ '00' ha) & $\mathbf{N e g}$ \\
\hline 8 & Wheat thresher (no./ '00' ha) & $\mathbf{0 . 2 0}$ \\
\hline 9 & Maize thresher (no./ '00' ha) & $\mathbf{N e g}$ \\
\hline 10 & Plough (no./ '00' ha) & $\mathbf{7 3 2 . 9}$ \\
\hline $\mathbf{1 1}$ & Chaff cutter (no./ '00' ha) & $\mathbf{8 . 7 9}$ \\
\hline $\mathbf{1 2}$ & Others (all types of Implements \& machinery & $\mathbf{3 6 1 . 1}$ \\
\hline
\end{tabular}

The production of three important food crops, namely, rice, maize and wheat, contributes a major portion of the food grain in the State and accounts for $84 \%$ of the total cropped area; the balance $16 \%$ is shared by other cereals and pulses (Table 4).

Nearly $75 \%$ of the country's temperate fruits, mainly apples, are grown in the State. Crop diversification towards less perishable horticultural crops like walnut, almond, pistachio, olive, kalazeera, saffron and pomegranate in the region is essential to earn foreign exchange and reduce pressure on the available resources for creating additional infrastructure facilities. The State is deficient in food grains production. Improved technologies have been developed which are superior to the traditional practices in terms of productivity and profitability but their adaptation is not comparable to the adoption level in Indo-Gangetic regions of India. The State needs to shift its agriculture development strategy from food security mode to the value addition mode by growing high value fruits, vegetables and some cash crops.

There is good scope for the production of high value, low volume crops like saffron, 
black zeera and other spices especially in Kashmir region.

\section{Brief scenario of fisheries sector}

There are 30,453 fishermen and 10,000 workers are employed in the fisheries sector which contributes 1.92 lakh quintals of fish production in the State during the year 20062007. However, there has been a big gap between demand and supply of fish. The State has potential of producing over 40 million $t$ of fish along the length of $27,781 \mathrm{~km}$ of rivers and streams in the State. There are 18 Stateowned trout hatcheries and 22 fish farms. There is good scope for expanding employment opportunities through the development of this sector.

\section{Brief scenario of livestock sector}

The State has a precious wealth of livestock in forms of cattle-buffalo, sheep, goats, poultry, etc. The cattle and poultry amongst all the livestock are considered the most important tools for the development of the rural economy. On an average there were 6.38 animals per household (livestock census2003). The production of pashmina shawls and other animal products like carpets, shawls and blankets of Kashmir earn handsome foreign exchange for the nation. Livestock activity contributes about $11 \%$ to the State GDP. Therefore livestock industry in the State has vast scope for development rendering quick economic returns. In terms of livestock production, there is a gap between demand and supply.

\section{Status of mechanization}

\section{Farm power availability}

The availability of farm power per unit area $(\mathrm{kW} / \mathrm{ha})$ has been considered as one of the parameters for expressing level of mechanization. Farm machinery use depends upon the farm power available for various tractive and stationary operations. At present, the availability of farm power is $0.78 \mathrm{~kW} / \mathrm{ha}$ in the State (gross cropped area basis) whereas the National average (projection) is $2.0 \mathrm{~kW} / \mathrm{ha}$. There is great variability in unit farm power availability within State i.e. it is as high as $3.06 \mathrm{~kW} / \mathrm{ha}$ in RS Pura and Bishna and as low as $0.47 \mathrm{~kW} / \mathrm{ha}$ in Ramnagar areas of Jammu region of the State (Sharma, 2009; Sharma, 2010). Draught animals continue to provide major tractive power for field operations in the State. Animate power (draught animals and human power) and mechanical power contributed $51.2 \%$ and $38.4 \%$ of the total farm power respectively during 2005-06 (Figure 8). It indicates that animate power still plays a major role in sources of farm power. The availability of farm power in the State is very low and has much need for further mechanization.

\section{Mechanization potential}

The State possesses a huge potentiality to adopt selective mechanization rather than sweeping mechanization. The farmers face difficulties in timely completion of field operations due to lack of mechanization inputs like improved implements for tillage operation, puddling, sowing/planting, interculturing, irrigation equipment, plant protection, harvesting, threshing, drying and processing equipment. The application of mechanization technology would increase agricultural productivity. Consequently, labour tied up with manual farm operations would be released to higher value activities. Rice-wheat cropping system has potential to provide food and feed security in the State hence priorities should be given to these crops by adopting improved varieties along with mechanization inputs for timely and efficient operation. The farm power availability at 0.78 $\mathrm{kW} / \mathrm{ha}$ (gross cropped area basis) has 
potential for increase, as it is much lower than the national average of $2.0 \mathrm{~kW} / \mathrm{ha}$. There is tremendous need for the mechanical and electrical power sources and their matching implements to increase the cropping intensity. For stationery operations like water lifting, threshing, chaff Moreover, better performance of the existing farms would be gotten through timeliness of operations and minimization of avoidable losses that occur during harvest and post-harvest operations. Improved harvesting equipment like serrated sickles, fruit pluckers, vertical conveyer reapers and mini combine harvester could be introduced. To overcome drudgery in threshing and cleaning of cereals, pulses and oilseeds, appropriate power threshers could be adapted. Seasonal leafy vegetables and fruits like apple, pear, cherry, strawberry, almond, walnut, saffron and kalazeera (black zeera) could be used for value addition. This will be helpful in reducing the supply -demand deficit in off-season. Fruit crop mechanization equipment for pit making, transplanting of saplings, pruning, spraying in tall crops, harvesting of fruits etc. could be identified/ adopted/ developed and popularized. Cutting, cleaning, grading and other agro processing activities, adequate electrical energy is essential. In all the three regions of the State, animal power utilization is only $250-300 \mathrm{~h}$ annually (as against ideal utilization of 2,500 h). Most of the time the draught animals remain ideal due to limited period of use for tillage, sowing and puddling operations only. Farmers have to spend the money on the maintenance of draught animals for the entire year. Thus, the animal power is wasted without its optimum utilization. However, it is not possible to replace completely the animal power with the mechanical power. Besides, the State has a great number of draught animals (15.96 lakh). To maintain an eco-friendly system, there is a need to select, test and popularize animal drawn improved implements for tillage, sowing, puddling and intercultural operations.
This will increase the efficiency of animal and reduce the drudgery of the farmers. In addition, the ideal period of draught animals can be utilized for generation of electricity through rotary mode of operation. In the hilly areas of the State, power tiller matching implements for seed bed preparation, sowing, plant protection, harvesting, threshing etc. are relevant on small, irregular and undulated fields and could be introduced.

\section{Constraints of agricultural mechanization}

The choice, extent and adoption of mechanization for Jammu and Kashmir agriculture have some severe limitations mentioned below:

The most crucial is the economic conditions of the farmers as majority of the farmers are marginal and small.

The undulating topography and terraced irregular shape fields make mechanization difficult with farm equipment available in the market.

The availability and access to farm machines is very low due to lack of production and marketing facilities for farm implements in the State except Jammu region.

The packages of improved matching equipment with power tiller for agricultural operations have yet to be accepted by farmers of the region.

The custom hiring/ contract farming have not been emphasized on for commercialization of agriculture.

\section{References}

Anonymous. 2005. Long-term Mechanization Strategy Papers for Different Agro Climatic Zones. Indian Council of 
Agricultural Research New Delhi110012

Anonymous. 2015-16. Digest of Statics of Jammu and Kashmir. Dept. of Statics, Jammu and Kashmir, India.

Dixit, J, Sharma. S and Ali. M, 2014 Present status, potential and future needs for mechanization of agricultural operations in Jammu and Kashmir State of India CIGR Journal 16(3): 87-96

Dixit, J., A. S. Jeena, N. C. Shahi, and T. Wahid. 2006. Potential of farm mechanization in Jammu and Kashmir State of India-A review. Agricultural
Mechanization in Asia, Africa and Latin America, 37(4): 9-14.

Sharma S. 2009. Status of farm power availability in the selected villages of Jammu District (J\&K State). Agricultural Mechanization in Asia, Africa and Latin America, 40(10): 4145.

Sharma S. 2010. Status of farm power availability in the selected villages of Udhampur District (J\&K State). Journal of Dryland Agriculture Research \& Development, 25(1): 70-73.

\section{How to cite this article:}

Sunny Raina, Hemant Dadhich, Anil Kumar, Brinder Singh and Jai Kumar. 2018. Status, Scope and Constraints of Farm Mechanization in Jammu and Kashmir State of India. Int.J.Curr.Microbiol.App.Sci. 7(03): 1279-1286. doi: https://doi.org/10.20546/ijcmas.2018.703.152 